\title{
Evaluating the Effect of Algal Extracts against Ultraviolet B-Induced Skin Damage in BALB/c Mice
}

\author{
Abdullah Trad Al-fawwaz, Mariam Abu-AL-Basal and Hala Ali Tawil \\ Department of Biological Sciences, Al al-Bayt University, Mafraq 25113, Jordan
}

\begin{abstract}
Ethanol extract of mixed algae — spirogyra and ulothrix was investigated to assess the effect on some biochemical parameters in UVB irradiated mice. The dorsal-thoracic region of mice were shaved and exposed to UVB radiation for $24 \mathrm{~h}$ for two consecutive weeks. Five groups of ten mice each were conducted: non-irradiated control and irradiated control. Mice treated with commercial cream (S.M.) at a dose of $0.1 \mathrm{mg} / \mathrm{cm}^{2}$ and mice treated with ethanol extract of mixed spirogyra and ulothrix at a dose of $0.1 \mathrm{mg} / \mathrm{cm}^{2}$ or $0.2 \mathrm{mg} / \mathrm{cm}^{2}$. Topical application was performed to all treated mice groups once a day for four consecutive weeks. Results showed significant differences between treated and control groups during the whole period of experiment. The clear potentiality of the ethanol extract was detected through body and skin weight, level of total protein, Superoxide Dismutase (SOD) and Catalase (CAT) activities in skin. However, UVB irradiated mice treated with $0.2 \mathrm{mg} / \mathrm{cm}^{2}$ exhibited the most significant effect when compared to control groups. That may be attributed to anti-inflammatory and anti-oxidant effects of algal extract.
\end{abstract}

Key words: Algae, ultraviolet radiation, photoprotective.

\section{Introduction}

Light is broadly divided into Infrared Radiation (IR), Visible Light (VIS) and Ultraviolet Radiation (UVR) [1]. UVR is defined as that portion of the electromagnetic spectrum between $\mathrm{X}$ rays and visible light between $40 \mathrm{~nm}$ and $400 \mathrm{~nm}$. Solar UVR at the earth's surface consists of approximately 95\% UVA (320-400 nm), 2\%-5 \% UVB (280-320 nm) and all the UVC $(200-280 \mathrm{~nm})$ which is absorbed by stratospheric ozone [2]. Free radicals will be formed when the skin irradiated with UV light, those free radicals will immediately interact with the living cells and cause harmful oxidation effects on epidermal protein, lipids and epidermal DNA [3, 4].

In recent years, the protection of skin from photo-damage by using algal extracts and some other means is an urgent concern. One strategy for safeguarding the skin from UV radiation is by blocking the UV radiation exposed on the epidermis by using the sunscreens [4, 5]. Recent studies

Corresponding author: Abdullah Trad Al-fawwaz, Ph.D., main research fields: microbial biotechnology, environmental control and algal ecology. indicate that numerous novel compounds have been isolated from marine organisms during the last four decades and many of these substances have been demonstrated to posses interesting biological activities [6]. Research on local marine organisms had considerable attention in recent years, however, few previous studies have been reported revealing the effect of algae on UVB-irradiated skin. Hence, this study was performed to investigate the photoprotective effects and healing property of algae extract by evaluating its effect against UVB-induced skin damage in $\mathrm{BALB} / \mathrm{c}$ mice.

\section{Material and Methods}

\subsection{Questionnaire}

In order to effectively compare the effect of natural cream containing algal extract with commercial one, determining the most popular commercial cream that women use is important. This was achieved by interview questionnaire. The major group (200 students in Al al-Bayt University, Jordan) which was targeted in this project was female adults between the ages of 18 and 30. Questions which were addressed 
included student's age, sunscreen commercial name and Sun Protective Factor (SPF).

\subsection{Sampling of Algae}

Samples were collected from different sampling sites in the north of Jordan. Water samples containing algae were collected at several locations from different sites in Jordan between January and December 2013. The physical parameters were recorded. Each sample was labeled, kept in special plastic bags and plastic containers and directly transferred to the laboratory. Upon arrival to the laboratory, the samples were divided to three parts, the first one was inoculated on Bolds Basal Media (BBM) agar plates, the second part was inoculated in $250 \mathrm{~mL}$ sterile Erlenmeyer flasks which contain $100 \mathrm{~mL}$ BBM medium, and the rest was kept at $4{ }^{\circ} \mathrm{C}$ in the fridge [7]. All flasks which inoculated with water samples were incubated for 15 days under continuous illumination at an average intensity of 1,500 Lux $\left(20.25 \mu \mathrm{mol}\right.$ photon $\left.\cdot \mathrm{m}^{-2} \cdot \mathrm{S}^{-1}\right)$ provided by white-cool fluorescent lamps at $25 \pm 2{ }^{\circ} \mathrm{C}$. BBM agar plates were inoculated from these flasks and incubated in the same conditions $(1,500 \mathrm{Lux}$ and $\left.25 \pm 2{ }^{\circ} \mathrm{C}\right)$ [8].

\subsection{Culture and Classification of Algae}

Samples were grown in $3 \mathrm{~L}$ cotton-sealed flasks with 1,200 mL Bolds Basal Media (BBM) [9]. Cultures were incubated in a growth chamber at $25 \pm$ $2{ }^{\circ} \mathrm{C}$ under $1,500 \mathrm{Lux}\left(20.25 \mu \mathrm{mol}\right.$ photon $\left.\cdot \mathrm{m}^{-2} \cdot \mathrm{S}^{-1}\right)$ of continuous illumination by white-cool fluorescent lamps. Cultures were shaken three times every day. Approximately every 14 days, cells were transferred to the fresh sterile medium to maintain all exponential growth phase. Light microscope was used to observe the morphological characteristics of the isolated algae species.

\subsection{Sunscreen Cream Preparation Method}

The algae were filtrated and purified from impurities, and then dried in the oven under $60{ }^{\circ} \mathrm{C}$ for 24 hours. Dried algae (10 g) were finely grounded and mixed with $100 \mathrm{~mL}$ of ethanol for $24 \mathrm{~h}$. Algal extract was concentrated by rotary evaporator until the ratio 100:20 was achieved, and then algal extract was separated by centrifugation at 3,500 rpm for $10 \mathrm{~min}$. Supernatant was then used to prepare the algal sunscreen. Algal extract was weighed and dissolved in the cold cream in two ratios $(1: 1$ and $2: 1$, extract:cream and wt:wt).

\subsection{Animals}

Male BALB/c mice-2 months old (20-22 g) from the animal house of the Department of Biological Sciences at Yarmouk University were used in the study. Mice were housed, fed and treated in accordance with the international guidelines principles of laboratory animal use and care during the whole period of the experiment [10].

\subsection{Exposure to UVB Radiation}

Mice were shaved dorsally with electrical clippers under mild $3.5 \%$ chloral hydrate anesthesia. The mice were allowed to move freely and irradiated within their cages. The mice back were at a distance of $20 \mathrm{~cm}$ from the UV lamps. UVB group mice were irradiated $24 \mathrm{~h}$ daily with UVB light during 2 weeks. Control group mice were shaved similarly and were not exposed to UVB radiation.

\subsection{Experimental Design}

Mice were randomly divided into control and experimental groups of ten mice each. Applications of treatments were performed to all animal groups by topical application once a day for two weeks. Five groups of mice were prepared and assigned as:

Group I: normal mice left without UVB radiation and treatment, as normal control;

Group II: UVB-irradiated mice left without treatment, as negative control;

Group III: UVB-irradiated mice treated with 
commercial cream $(\mathrm{SM})$ at a dose of $0.1 \mathrm{mg} / \mathrm{cm}^{2}$, as positive control;

Group IV: UVB-irradiated mice treated with mixed Spirogyra and Ulothrix ethanol extract at a dose of 0.1 $\mathrm{mg} / \mathrm{cm}^{2}$;

Group V: UVB-irradiated mice treated with mixed Spirogyra and Ulothrix ethanol extract at a dose of 0.2 $\mathrm{mg} / \mathrm{cm}^{2}$.

\subsection{Measurement of Body Weight}

Body weight of each animal in control and experimental groups was measured and recorded immediately before exposure to UVB radiation and again at weeks 2 and 4 after treatment.

\subsection{Measurement of Skin Weight}

The skin was excised from six animals per each group at the end of the experimental period and immediately weighted to estimate skin weight.

\subsection{Tissue Sampling and Biochemical Analysis}

Skin samples were excised from control and experimental groups at weeks 2 and 4 after treatment. They were homogenized in neutral phosphate buffer saline under ice, centrifuged and the collected supernatant was analyzed for total protein, superoxide dismutase and catalase as:

\section{- Total Protein}

Level of total protein was determined by Coomassie Blue G method, using Quanti Chrom protein assay kit. The intensity of color was measured at $595 \mathrm{~nm}$. Total protein level was expressed in $\mathrm{mg} / \mathrm{mL}$.

\section{- $\quad$ Superoxide Dismutase (SOD)}

Activity of SOD was determined by convenient colorimetric method, using EnzyChrom superoxide dismutase assay kit. SOD activity was expressed in $\mathrm{U} / \mathrm{mL}$.

\section{- Catalase (CAT)}

Activity of CAT was determined by degradation of $\mathrm{H}_{2} \mathrm{O}_{2}$ using EnzyChrom Catalase Assay Kit. The intensity of color was measured at $570 \mathrm{~nm}$. CAT activity was expressed in U/L.

\subsection{Statistical Analysis}

Data were entered into a personal computer and analyzed using the Statistical Package for Social Sciences (SPSS) software version 11.0. Means and standard errors were calculated. Furthermore, one way ANOVA test with Tukey post hoc and paired $t$ test were used to compare among tested groups. The level of significance was set at $\mathrm{p} \leq 0.05$.

\section{Results}

Two algae species were isolated from local environment and identified as Spirogyra and Ulothrix species (Fig. 1) according to morphological and microscopic analysis performed at $\mathrm{Al}$ al-Bayt University.

\subsection{Effect of Mixed Spirogyra and Ulothrix Ethanol} Extract on Body Weight of the Control and Experimental Groups

UVB-irradiated mice treated with ethanol extract of mixed Spirogyra and Ulothrix revealed significant decrease in body weight when compared to non-irradiated control (Table 1). The most significant improvement in body weight was observed at 4 weeks after treatment. Mice treated with ethanol extract of mixed Spirogyra and Ulothrix at a dose of $0.2 \mathrm{mg} / \mathrm{cm}^{2}$ skin showed considerable reduction in body weight $(22.0 \pm 0.5)$ compared with mice treated with 0.1 $\mathrm{mg} / \mathrm{cm}^{2}$ skin $(22.6 \pm 0.4)$. The same trend was observed in irradiated group treated with S.M. cream at a dose of $0.1 \mathrm{mg} / \mathrm{cm}^{2}$ skin when compared to non-irradiated control.

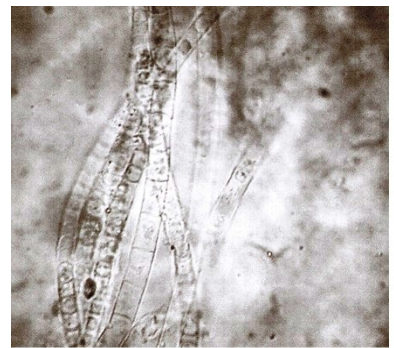

(a)

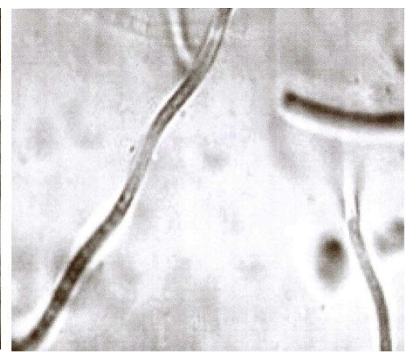

(b)
Fig. 1 Light microscope image of the isolated species (a): Spirogyra and (b): Ulothrix (magnification 100). 
Table 1 Effect of mixed Spirogyra and Ulothrix ethanol extract on body weight of the control and experimental groups.

\begin{tabular}{lll}
\hline \multirow{2}{*}{ Groups } & \multicolumn{2}{c}{ Week after treatment } \\
\cline { 2 - 3 } & 2 & 4 \\
\hline I & $20.4 \pm 0.5$ & $22.8 \pm 0.4$ \\
II & $22.0 \pm 0.3^{*}$ & $24.1 \pm 0.3^{*}$ \\
III & $21.0 \pm 0.3$ & $23.0 \pm 0.3$ \\
IV & $20.5 \pm 0.6^{* *}$ & $22.6 \pm 0.4^{* *}$ \\
V & $20.1 \pm 0.7^{* *}$ & $22.0 \pm 0.5^{* *}$ \\
\hline
\end{tabular}

* Data are expressed as means \pm SE for ten mice in each group.

*-Statistically significant when compared to non-irradiated control at $\mathrm{P}<0.05$;

**_-Statistically significant when compared to irradiated control at $\mathrm{P}<0.05$.

\subsection{Effect of Mixed Spirogyra and Ulothrix Ethanol} Extract on Skin Weight of the Control and Experimental Groups

UVB-irradiated mice showed significant increase ( $p$ $<0.05)$ in relative weight of skin when compared to non-irradiated control. While, significant decrease was noted in the relative weight of skin of mixed Spirogyra and Ulothrix treated mice as compared to non-irradiated control (Table 2).
3.3 Effect of Mixed Spirogyra and Ulothrix Ethanol Extract on Total Protein Level $(\mathrm{g} / \mathrm{dL})$ of the Control and Experimental Groups

Irradiated mice treated with mixed Spirogyra and Ulothrix ethanol extract showed significant increase of total protein level in two groups $(\mathrm{p}<0.05)$ for both low and high doses as compared to irradiated control (Fig. 2). The most significant enhancement in total protein level was observed at a dose of $0.2 \mathrm{mg} / \mathrm{cm}^{2}$ skin after 4 weeks of treatment (32.9 \pm 0.09$)$. However, there was a slight rise of total protein level in irradiated group treated with S.M. cream at 0.1 $\mathrm{mg} / \mathrm{cm}^{2}$ dose compared to irradiated control.

3.4 Effect of Mixed Spirogyra and Ulothrix Ethanol Extract on SOD Activity (U/mL) of the Control and Experimental Groups

Irradiated mice showed a significant decrease $(p<0.05)$ in activities of SOD when compared to non-irradiated control. However, irradiated mice treated with ethanol extract of mixed Spirogyra and Ulothrix revealed increase in the activity of SOD as

Table 2 Effect of mixed Spirogyra and Ulothrix ethanol extract on skin weight of the control and experimental groups.

\begin{tabular}{llllll}
\hline \multirow{2}{*}{ Skin } & \multicolumn{5}{c}{ Groups } \\
\cline { 2 - 5 } & I & II & III & IV & V \\
\hline 2 & $0.2 \pm 0.005$ & $0.3 \pm 0.002^{*}$ & $0.2 \pm 0.005$ & $0.2 \pm 0.005^{* *}$ & $0.2 \pm 0.005^{* *}$ \\
4 & $0.2 \pm 0.005$ & $0.3 \pm 0.003^{*}$ & $0.2 \pm 0.005$ & $0.2 \pm 0.004^{* *}$ & $0.2 \pm 0.005^{* *}$ \\
\hline
\end{tabular}

*-Statistically significant when compared to non-irradiated control at $\mathrm{P}<0.05$;

**_-Statistically significant when compared to irradiated control at $\mathrm{P}<0.05$.

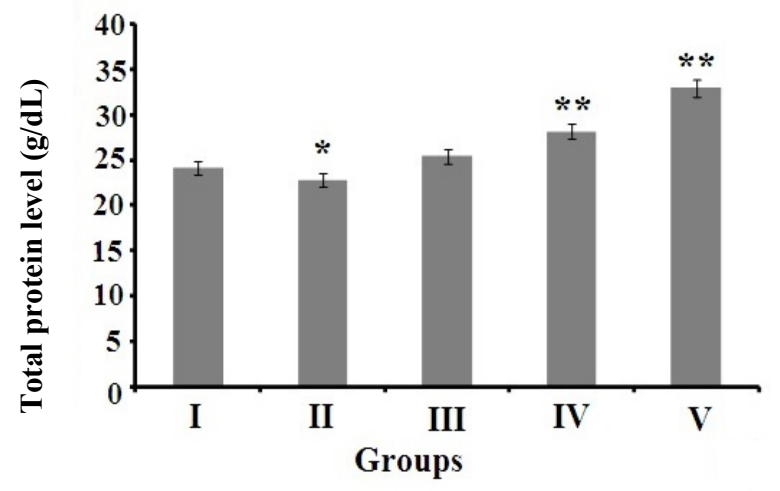

(a)

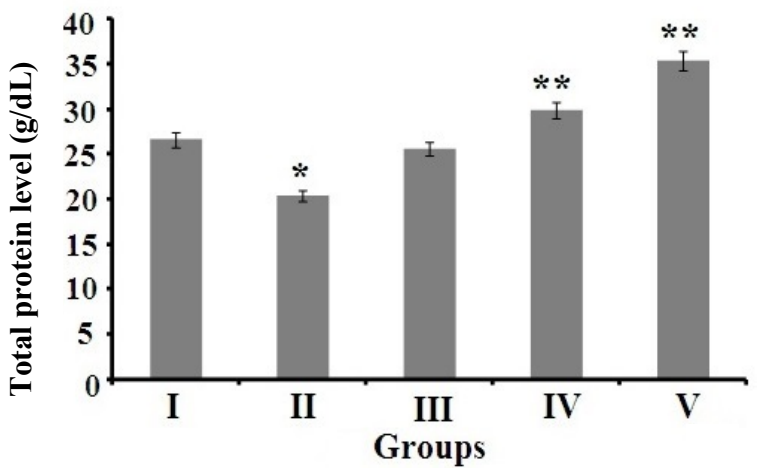

(b)

Fig. 2 Effect of mixed Spirogyra and Ulothrix ethanol extract on total protein level in skin (g/dL) of the control and experimental groups at 2 weeks (a) and 4 weeks (b) after treatment. 
compared to irradiated control (Fig. 3). The mainly increment in activity of SOD was noted after 4 weeks of treatment at dose $0.2 \mathrm{mg} / \mathrm{cm}^{2}$ compared with irradiated mice that was treated with $0.1 \mathrm{mg} / \mathrm{cm}^{2}$. In contrast, marked decrease in SOD was noticed in irradiated control.

\subsection{Effect of Mixed Spirogyra and Ulothrix Ethanol} Extract on CAT Activity $(U / L)$ of the Control and Experimental Groups

Irradiated mice treated with ethanol extract of mixed Spirogyra and Ulothrix revealed significant increase in CAT activity when compared to irradiated control (Fig. 4). The most significant enhancement in CAT activity was observed at 4 weeks after treatment. However, mice treated with $0.2 \mathrm{mg} / \mathrm{cm}^{2}$ skin showed considerable increase in CAT activity than that

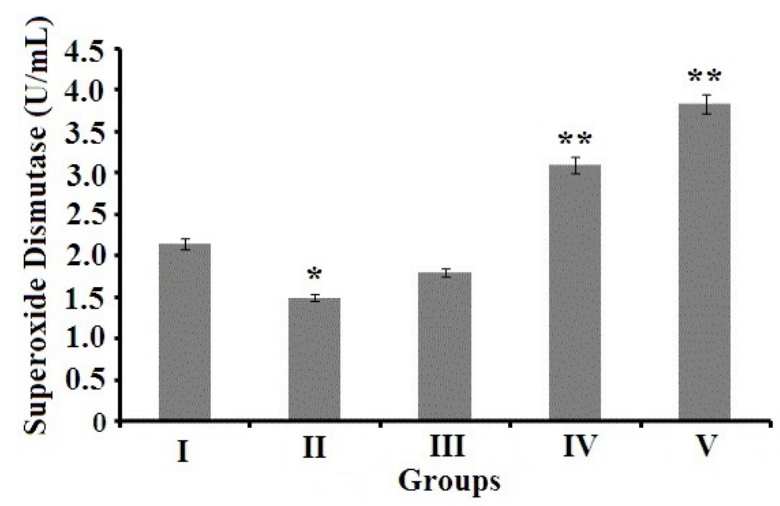

(a) observed in mice treated with $0.1 \mathrm{mg} / \mathrm{cm}^{2}$ and irradiated group treated with S.M. cream at a dose of $0.1 \mathrm{mg} / \mathrm{cm}^{2}$.

\section{Discussion}

The present study was performed to evaluate the effects of ethanol extract of mixed Spirogyra and Ulothrix on some biochemical parameters including level of total protein, Superoxide Dismutase (SOD) and Catalase (CAT) activities in skin of UVB-irradiated mice.

Ultraviolet (UVB) exposure resulted in a rise of experimental mice skin weight compared to that of normal control (Table 2). Enhancement in the skin weight might be due to damage the thickness of the dermal fat layer [11]. The increase in skin weight may be related to increase and dilatation of blood vessels [12].

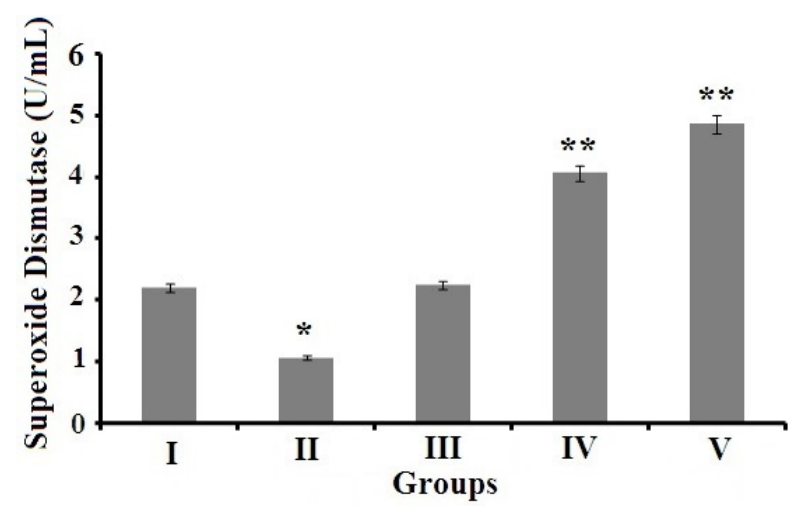

(b)

Fig. 3 Effect of mixed Spirogyra and Ulothrix ethanol extract on SOD activity in skin (U/mL) of the control and experimental groups at 2 weeks (a) and 4 weeks (b) after treatment.

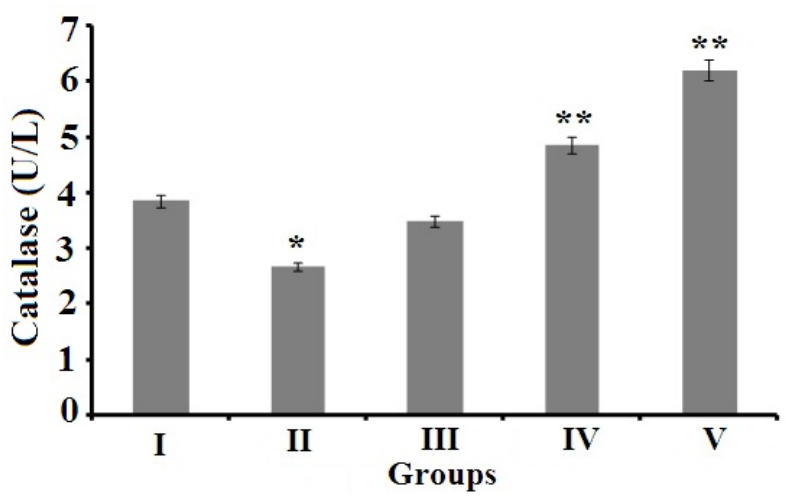

(a)

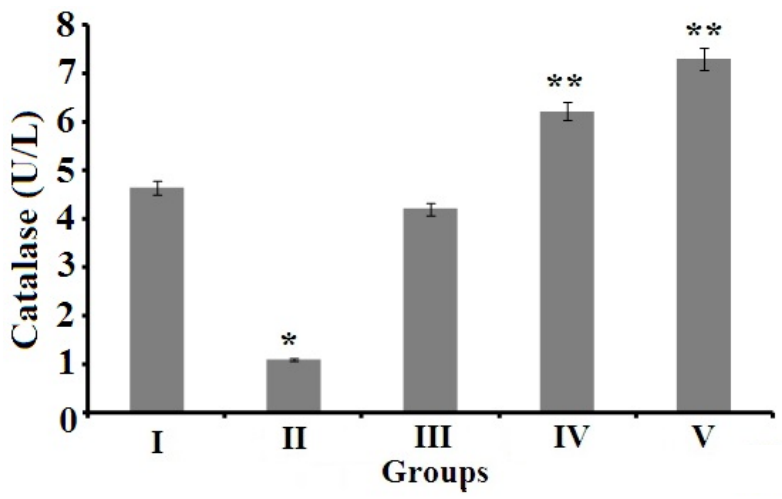

(b)

Fig. 4 Effect of mixed Spirogyra and Ulothrix ethanol extract on CAT activity in skin (U/L) of the control and experimental groups at 2 weeks (a) and 4 weeks (b) after treatment. 
The results obtained in this study showed damage in the weight of the skin in exposed mice. Whereas, this was prevented by a formulation containing ethanol extract of mixed Spirogyra and Ulothrix (Table 2).

Ultraviolet Radiation (UVB) has a direct effect on level or activity of antioxidant factors present in animal body living cells, including superoxide dismutase, catalase and form complexes with amino acids and protein. Thus, causes structural alteration and enzyme in activation [13].

Total protein level is considered to be a contributing factor in skin disorders, such as photo oxidative damage, the inhibition of UVB-induced protein oxidation by mixed algae may ameliorate photo oxidative damage of the skin [14].

Two foremost antioxidant defense enzymes in animal body living cells are SOD and CAT. The dismutation of superoxide by SOD results in the production of hydrogen peroxide, which is subsequently converted to water and oxygen through a reaction that is catalyzed by catalase. An imbalance in the ratio of antioxidant enzymes may thus contribute to an excessive accumulation of ROS, increasing oxidative stress and damage [15]. Antioxidants play a crucial role in ameliorating or indeed preventing photobiologic damage in vivo [16]. It has been reported that SOD activity is significantly suppressed by UVB radiation (Fig. 3) [17]. However, continual cumulative stress may overwhelm the capacity of this system, with SOD activity being significantly decreased in the skin [18]. In the present study, UVB radiation of the skin induced a significant reduction in SOD and activity compared to control group (Fig. 3). This result suggests that endogenous SOD is utilized to neutralize UVB-induced oxygen free radicals. UVB-induced modifications include changes in proteins involved in cell cycle activity, cellular repair, proliferation and apoptosis [19]. UVB radiation produces an increase in reactive oxygen species such as superoxide ion and hydrogen peroxide [20]. These radicals increase lipid peroxide levels in the skin. Hence, in cases of irradiation, SOD and its activities are sharply reduced [21]. If catalase is lacking, hydrogen peroxide and hydroxyl radicals increase in response to UVB radiation, since antioxidant enzyme (SOD) is inactivated by hydrogen peroxide [22]. Hydrogen peroxide generated during UVB radiation may inactivate SOD. Catalase absorbs UVB radiation of a broad wavelength band and thus becomes inactivated (Fig. 4). This phenomenon indicates that catalase may function to protect SOD against UVB radiation. However, other possibilities still remain. In the case of UVB exposures, which are a common condition of daily life, a deficiency of catalase may allow damage to the skin with a low defense function of SOD to take place [23]. The substantial rise in activity of SOD and CAT in skin tissues may generally be attributed to the increment in the production of these enzymes by reason of the therapeutic agents present in the ethanol extract of mixed Spirogyra and Ulothrix and the obtained values of SOD and CAT relatively reaching the normal level (Figs. 3 and 4).

Many studies have focused on marine organisms as a source of natural bioactive molecules with therapeutic properties, which are exploited in a multitude of commercial applications. Mixed Spirogyra and Ulothrix, besides constituting an important food source in Asian countries, are able to produce substances with anti-inflammatory and antioxidant properties with possible applications in the cosmetic, nutrition and pharmaceutical industry sectors [24].

The present study was aimed to show that the extract obtained from the mixed Spirogyra and Ulothrix has the potential to heal the mice after the damages produced by UVB radiation. Results showed that the ethanol extract of mixed Spirogyra and Ulothrix may have antioxidant activity which is able to inhibit lipid peroxidation and activate antioxidant enzymes. Antioxidant activity of ethanolic extracts 
may prevent or slow down the oxidative damage induced by UVB radiation in mice and as a result promote regeneration of damaged skin [25].

\section{Conclusions}

Chronic exposure to UV radiation may cause skin damage and carry a risk of skin cancer. Therefore, people need new strategies to overcome UV skin damage problems. These results demonstrate that treatment UVB-irradiated mice with mixed Spirogyra and Ulothrix ethanol extract at a dose of $0.1 \mathrm{mg} / \mathrm{cm}^{2}$ or $0.2 \mathrm{mg} / \mathrm{cm}^{2}$ skin for 4 consecutive weeks promotes decreasing in body and skin weight, while increasing levels of total protein, SOD and CAT activities in skin. Therefore, these results suggest that algal extracts may exhibit some potential to prevent photo-damage. Mixed Spirogyra and Ulothrix ethanol extract may prevent or slow down the oxidative damage induced by UVB-radiation in mice, which require further scientific verification.

\section{Acknowledgements}

The authors express their gratitude to $\mathrm{Al}$ al-Bayt University for using facilities in the Department of Biological Sciences and their technical and financial assistance.

\section{References}

[1] Anitha, T. 2012. "Medicinal Plants Used in Skin Protection." Asian J. Pharm. Clin. Res. 5: 35-38.

[2] Mishra, A., Mishra, B., and Chattopadhyay, P. 2011. "Herbal Cosmeceuticals for Photoprotection from Ultraviolet B Radiation." Tropical Journal of Pharmaceutical Research 10: 351-360.

[3] Darvin, M. E., Gersonde, I., Albrecht, H., Sterry, W., and Lademann, J. 2006. "In Vivo Raman Spectroscopic Analysis of the Influence of UV Radiation on Crotenoid Antioxidant Substance Degradation of the Human Skin." Journal of Clinical Laser Medicine 5: 833-837.

[4] Avila Acevedo, J. G., Espinosa González, A. M., De-Maria Campos, D. M., Benitez Flores, J. C., Delgado, T. H., and Maya, S. F. et al. 2014. "Photoprotection of Buddleja cordata Extract against UVB-Induced Skin Damage in SKH-1 Hairless Mice." BMC Complementary and Alternative Medicine 14: 281-290.

[5] Balakrishnan, K., and Narayanaswamy, N. 2011. "Botanicals as Sunscreens: Their Role in the Prevention of Photoaging and Skin Cancer." International Journal of Research in Cosmetic Science 1: 1-12.

[6] El-Gamal, A. A. 2010. "Biological Importance of Marine Algae.” Saudi Pharmaceutical Journal 18: 1-25.

[7] Andersen, R., and Kawachi, M. 2005. "Traditional Microalgae Isolation Techniques." Algal Culturing Techniques 83: 90-101.

[8] Preising, H., and Andersen, R. 2005. "Historical Review of Algal Culturing Techniques." Algal Culturing Techniques 65: 79-82.

[9] Guillard, R., and Ryther, J. 1962. "Studies of Marine Planktonic Diatoms: I. Cyclotella nana Hustedt, and Detonula confervacea (Cleve) Gran." Canadian Journal of Microbiology 8: 229-239.

[10] Suckow, A. M., Weisbroth, H. S., and Franklin, L. C. 2006. The Laboratory Rat, 2nd Ed. New York: Elsevier Inc..

[11] Lu, Y. P., Lou, Y. R., Peng, Q. Y., Xie, J. G., Nghiem, P., and Conney, A. H. 2004. "Stimulatory Effect of Topical Application of Caffeine on UVB-Induced Apoptosis in the Epidermis of P53 and Bax Knockout Mice." Cancer Res. 64: 5020-5027.

[12] Khamees, N. H., Insaf, J. M., and Amal, K. 2012. "Effects of Combined Oral Contraceptives on the Skin of Mice." Turkish Journal of Medical Sciences 2: 1528-1537.

[13] Nduka, N. 1999. "Clinical Biochemistry for Students of Pathology." Longman Nigerian 1: 234-236.

[14] Aleksandar, G., Borut, P., Metka Adamic, A., and Raja, D. 2014. "The Role of Antioxidants in Skin Cancer Prevention and Treatment." Oxidative Medicine and Cellular Longevity 2014: 1-6.

[15] Hellemans, L., Corstjens, H., Neven, A., Declercq, L., and Maes. D. 2003. "Antioxidant Enzyme Activity in Human Stratum Corneum Shows Seasonal Variation with an Age-Dependent Recovery." Journal of Investigative Dermatology 120: 434-439.

[16] Farris, P. K. 2005. "Topical Vitamin C: A Useful Agent for Treating Photoaging and Other Dermatologic Conditions.” Dermatology Surgery Journal 31: 814-817.

[17] Hwang, K. I., Yoo, K. Y., Kim, D. W., Jeong, S. J., Won, C. K., and Moon, W. K. et al. 2006. "An Extract of Polygonum Multiflorum Protects against Free Radical Damage Induced by Ultraviolet B Irradiation of the Skin." Brazilian Journal of Medical and Biological Research 39: 1181-1188.

[18] Cleaver, J. E., and Crowley, E. 2002. "UV Damage, DNA Repair and Skin Carcinogenesis." Front Bioscience Journal 7: 1024-1043. 
[19] Gruijl, F., Van, K. H., and Mullenders, H. 2001. "UV-Induced DNA Damage, Repair, Mutations and Oncogenic Pathways in Skin Cancer." Journal of Photochemistry and Photobiology B 63: 19-27.

[20] Romeu, M., Mulero, M., Giralt, M., Folch, J., Nogues, M. R., and Torres, A. 2002. "Parameters Related to Oxygen Free Radicals in Erythrocytes, Plasma and Epidermis of the Hairless Rat." Life Science Journal 71: 1739-1749.

[21] Aricioglu, A., Bozkurt, M., Balabanli, B., Kilinc, M., Nazaroglu, N. K., and Turkozkan, N. 2001. "Changes in Zinc Levels and Superoxide Dismutase Activities in the Skin of Acute, Ultraviolet-B-Irradiated Mice after Treatment with Ginkgo biloba Extract." Biological Trace Element Research 80: 175-179.

[22] Khalid, Rahman. 2007. "Studies on Free Radicals,
Antioxidants, and Co-factors." Clinical Interventions in Aging 2: 219-236.

[23] Moysan, A., Marquis, I., Gaboriau, F., Santus, R., Dubertret, L., and Morliere, L. 1993. "Ultraviolet an Induced Lipid Peroxidation and Anti Oxidant Defense Systems in Cultured Human Skin Fibroblasts." Journal of Investigative Dermatology 100: 692-698.

[24] Gonza, I. D., Val, A., Basilio, G., and Cabello A. 2001. "Screening of Antimicrobial Activities in Red, Green and brown Macroalgae Platas, from Gran Canaria (Canary Islands, Spain International)." Journal of Microbiology 4: $35-40$.

[25] Katiyar, S. 2008. "Grape Seed Proanthocyanidins and Cancer Prevention: Inhibition of Oxidative Stress and Protection of Immune System." Molecular Nutrition and Food Research 52: 871-876. 